\title{
Landscape, time and cultural resilience: a brief history of agriculture in Pokot and Marakwet, Kenya
}

\author{
Matthew I.J. Davies* and Henrietta L. Moore** \\ * Lecturer in African Studies, University College London \\ ** Director, Institute for Global Prosperity, University College London
}

\begin{abstract}
The Marakwet and Pokot communities of northwest Kenya are keen farmers, especially known for their creation of extensive pre-colonial irrigation networks. Over the last century both communities have been subjected to a range of external agricultural interventions but Marakwet and Pokot farming remains largely based on practices with a deeper history. We argue, however, that this continuity through time also masks smaller-scale innovations, movements and changes that attest to a dynamic, yet hidden 'cultural resilience' spanning several centuries. We explore this deeper history through a range of archaeological, ethnographic and historical data and use this analysis to re-think the various agricultural narratives and interventions previously employed in the region.
\end{abstract}

Keywords: archaeology; anthropology; agriculture; resilience; Kenya; Marakwet; Pokot

\begin{abstract}
"One of the key themes that recurred time and again was the need to identify and accord due recognition to the scientific, technological and organisational know-how of the local [Kerio Valley] communities before embarking on development projects. Incorporating this cultural base into development plans is not only cost effective in terms of technology, finance and human resources, it is bound to enhance community participation in all the phases of development projects". ${ }^{1}$
\end{abstract}

The western Elgeyo Escarpment of the Kerio Valley and adjoining Cherangani Hills in northwest Kenya is home to two interrelated communities, the agricultural sections of the Pokot and their neighbours the Marakwet (Fig.1). The Marakwet have been well studied in relation to a range of topics ${ }^{2}$ while the agricultural Pokot have also received attention in recent years ${ }^{3}$. Both communities have drawn particular notice due to their relatively intensive farming techniques including complex networks of pre-colonial irrigation ${ }^{4}$. However, few studies have attempted to place these farming practices in a broader context, situating the Pokot and Marakwet in relation to temporal patterns of landscape change and in terms of broader regional networks and exchanges. However, the last three decades of 
research have failed to influence development trajectories as Kipkorir had hoped. The aim of this paper is to begin thinking about the longer-term histories of these communities, their recursive relations with their environment and their neighbours, and their enduring persistence through the lens of cultural resilience.

INSERT Figure. 1. Geographic locations of the agricultural Pokot and Marakwet.

Cultural resilience, as we understand it, is not a discrete property - something that societies or systems either possess or lack - but rather a set of contextually emergent attributes (thoughts, behaviours, knowledges, values and resources) that intersect across different social networks, identities, scales and institutions within lifetimes, across generations and through historical time. These attributes are not fixed but operate through continuities of practice, ranging from daily subsistence activities through continuity of ritual and belief to the transition of knowledge contained in stories and myths. Such daily practices themselves are improvised rather than determined by static 'tradition', although those improvisations are gradually incorporated into the body of practices, ideas and values perceived as tradition. 'Traditions' and local perceptions of history not only constitute therefore a framework for continuity and stasis, but also provide the means for adaptation and change through normalising dynamic new actions and incorporating useful new environmental knowledge into mainstream consciousness. Indeed both internal (insider) and external (outsider) ideas of continuity, timelessness and 'backwardness' often act to mask actual dynamic change to hide resilience.

We consider this dialectic relationship between perceived modernity and tradition, between change and continuity to be a key aspect of cultural resilience, and an important attribute of both the Marakwet and Pokot communities. We argue here that resilient societies, like the Marakwet and Pokot, are perhaps those which change without explicit articulated recognition of the extent and character of change because flexible adaptation and innovation is a relatively unperceived part and parcel of daily life grounded in practical continuities. Understanding such resilience thus requires an approach that explores both 
time and space (landscape) across the ranges of human experience (i.e. lifetime, generation, kin-group, 'ethnicity', economy).

We find approaches grounded in everyday experience to be a particularly useful starting point through which to grasp the broader facets of cultural resilience. The spatial and temporal activities of daily life (the 'taskscape' sensu Ingold ${ }^{5}$ ) often nest within longerterm routines or cycles with wider spatial affects ${ }^{6}$. The daily activity of clearing agricultural fields in March foreshadows the annual cycles of planting, weeding and harvesting, but also reflects longer-term patterns of soil modification (fertility, erosion, deposition), vegetation change and re-growth, and patterns of shifting cultivation and settlement. These changes are physically written into the landscape in patterns and histories of soil, crops and vegetation, as well as field boundaries, irrigation channels and past habitation sites. These cycles likewise inform the social calendar - initiations, weddings etc. - and thus the spatial and temporal reproduction of human life as can be seen in the physical growth and decline of individual households ${ }^{7}$ and the longer-term composition and locality of entire descent groups $^{8}$. In this brief history we focus on the broader-scale patterns of population, residence, land-use and intervention as traced in the landscape using archaeological, palaeoecological and oral historical approaches, but these in-turn are informed by our understanding of shorter-term and more localised daily practices.

We further argue that together these combined social and ecological cycles constitute the 'technologies of life' that regulate the management of resources along the Elgeyo Escarpment and Kerio valley. As we present below and elsewhere, the Marakwet and Pokot employ a diverse range of techniques with regard to the management of water, soils, and crops - much of which we are only just beginning to appreciate. This suite of techniques likely has a history of two or more centuries, but at the same time these communities and their lifeways have continued to refine and evolve. Both the Pokot and the Marakwet have dynamically adopted innovations and new ideas while resisting regular external attempts at wholesale change.

As explored below, strong social institutions of ecological management, especially of water and soils, combined with the ability to move fields and homes across the landscape, to maintain extensive social networks at times of adversity, adopt new crops without 
loosing older ones, and to avoid wholesale dependence on externally driven agenda, all seem to have acted to buffer the Pokot and Marakwet from some of the challenges experienced by others. The comparative study of such 'technologies of life' within communities such as the Marakwet and Pokot, against others which appear to have been historically less successful, should form an important aspect of future social and physical science in Eastern Africa - not least because the impending challenges of climate change and rapid 'development' (for better or worse) seem unavoidable.

\section{Introduction to the agricultural Pokot and Marakwet}

The Pokot and Marakwet are members of the Kalenjin group of southern Nilotic speakers. Today the agricultural Pokot live in the northern Cherangani Hills, from Kapenguria in the south to the smaller Seker range in the north. They are surrounded to the west, north and east by interrelated sections of the pastoral Pokot and in the southeast by the Marakwet. The Marakwet inhabit a $40 \mathrm{~km}$ long stretch of the Elgeyo escarpment running north south from Arror in the south to the Pokot border at Chesegon in the north, and in the Cherangani hills to the west. They too are bounded by the pastoral Pokot in the east. Both communities extend their activities from the forest line around 2500 meters above sea level (masl) through the foothills and on to the lower-lying colluvial and alluvial plains around 1000 masl. Rainfall varies considerably across the region from up to $1400 \mathrm{~mm}$ in the highlands to around $600-900 \mathrm{~mm}$ on the valley floor, although both communities utilise extensive pre-colonial irrigation networks to channel water from highland streams into lower level fields ${ }^{9}$. In both communities a range of soil conservation measures are also well understood and include various forms of hillside terracing, manuring and mulching although these tend to be more visible in Pokot ${ }^{10}$.

Land-use and settlement patterns exhibit strong similarities between the Pokot and Marakwet parts of the region with land-use and access is conditioned in both areas by complex systems of kinship-based land-tenure ${ }^{11}$ and managed through effective communal decision making processes such as the kokwa or meeting of elders ${ }^{12}$. In the Wei wei Valley of Pokot, higher altitudes and more gentle slopes allow for largely household-based cultivation around and between hillside homesteads as well as along the valley floor. In Marakwet the steep Elgeyo escarpment encourages settlement on the hillside but limits 
major cultivation to the flatter valley floor, with smaller plots around households on the escarpment. Here a complex system of both semi-permanent and shifting cultivation occurs with the former largely managed at the household level and the latter a more communal operation $^{13}$. Primary cultivars include maize, sorghum, finger millet, cassava and a range of fruits and vegetables with complex patterns of intercropping, rotation and fallow. In both communities access is maintained to a range of resources across altitudinal and ecological zones, both through direct cultivation of plots at different elevations, as well as through complex social exchange and kin networks alongside numerous regional markets ${ }^{14}$. These networks link the highlands with pastoral lowlands via the intermediate Pokot and Marakwet communities in the foothills of the northern Cherangani and Kerio Valley. Such networks also link horizontally across the region, north-south/east-west and across ethnic (Pokot-Marakwet) and economic (farmer-herder) boundaries ${ }^{15}$.

Taken together we argue that systems of water and soil management ${ }^{16}$, kinshipbased land-tenure, crop and other ecological knowledge, and cross-region networks constitute a sophisticated series of technologies of life. The adaptability and effectiveness of these technologies can be assessed through the historical and archaeological record and what follows offers an outline of our current understanding of Pokot and Marakwet resilience across time and space. This is not to say that these agricultural systems are without challenges, or that they do not require support, but rather to point out that they have proven remarkably resilient and that the history of such successes must be taken into account when undertaking assessment of contemporary agricultural practice.

\section{Origins and deep history}

Oral histories attest to a fairly recent twentieth century Pokot movement southwards into the Cherangani massif from a core homeland around the foothills of the northern Cherangani and Seker Hills and focussed on the modern-day locations of Sigor and Marich ${ }^{17}$. However, this recent broader-scale movement seems to be the product of smaller-scale developments stretching back into the eighteenth century. Archaeological research around Sigor and into the Wei wei Valley around the village of Tamkal has identified, excavated and dated number of a sites suggesting an initial settlement of livestock keepers around Sigor c. AD $1750^{18}$. Most notable is the site of Ortuso Village (S202) 
where extensive scatters of cattle bone, ash and grindstones are found in conjunction with pottery of the Sirikwa or Lanet type with distinctive twisted cord roulette patterning and a globular vessel shape ${ }^{19}$. At earlier periods these ceramics are associated with Sirikwa agropastoralists who extended across the western highlands and Central Rift Valley of Kenya from c. AD 1200 to AD 1800. Although challenging to calibrate, a single radiocarbon date from Ortuso seems to confirm this picture (240 \pm 24 bp OxA-18868). Additional excavation and dating (both radiocarbon and thermoluminescence) of habitation sites from within the Wei wei Valley would place Ortuso into a sequence which sees the gradual expansion of early Pokot settlement up and into the valley from the Sigor region over the subsequent 250 years and continuing southwards into the Cherangani today. This settlement picture is supported by the oral and radiometric dating of irrigation channels from the same valley, which show extensive initial land-use and water management around Sigor and the subsequent shift of these southwards and into the valley, resulting in the intensive irrigated and part-terraced landscape of today.

It seems highly likely that the early Pokot community, or rather the community that becomes the Pokot, results from the disturbances and displacements caused by the breakup of the Sirikwa way of life which was, in turn, the result of Maasai intrusions from the $16^{\text {th }}-17^{\text {th }}$ century onwards. This situation is born-out in the distinctive Sirikwa ceramics found at Ortuso Village and elsewhere in the northern Cherangani and a range of radiometric $^{20}$ and oral historical data ${ }^{21}$ which place this initial 'proto-Pokot' settlement somewhere in the early $18^{\text {th }}$ century (Fig.2). Following this initial settlement the archaeological and oral historical data from the Wei wei Valley and oral histories from pastoral Pokot sections attest to a two-fold expansion of the Pokot community. From around AD 1750 onwards, agricultural Pokot extended and intensified specialised agricultural production southwards into the Cherangani Hills, while pastoral sections tended towards more specialised 'pure' forms of mobile pastoralism and expanded both west into present-day Uganda and east into Baringo.

Although direct radiometric dates for settlement in the Marakwet section of the Kerio Valley are yet to be obtained, we currently see little reason to assume that the pattern is considerably different from that in Pokot. Limited landscape survey has uncovered rouletted ceramics across the floor of the Kerio Valley near Tot with the same distinctive 
Sirikwa style which itself matches twentieth century Marakwet pottery ${ }^{22}$. Household plans, elements of material culture and irrigation technology in Marakwet are also similar to that found in Pokot suggesting at least some broad common origins. Marakwet oral histories of clan movements are detailed but too complex to recount in full here. It seems safe to say, however, that there have clearly been multiple independent movements into the region over a period of time preceding the last century. It also seems likely that the broader processes at work in the break-up of the Sirikwa community and the formation of the Pokot were the same as those which established the current locations of the Marakwet clans. One must further remember that the Marakwet cannot be considered a single ethno-linguistic group prior to the colonial period and that previously there had been at least three distinct communities - the Marakweta, Endo and Sengwer - with their own sub-divisions. In this sense some agricultural sections of the Pokot might also be considered the northernmost of this radiation of broadly Kalenjin speaking peoples.

While considerable research remains to be conducted, based on our current reading of the archaeological and oral historical data we tend towards the notion that extensive agricultural settlement in the northern Cherangani and Kerio Valley does not exceed two rotations of the interrelated Marakwet-Pokot age-set cycles and thus has a time depth of no more than 300 years. As well as the data recounted above, this assumption also draws on the idea that informants both in Pokot and in Marakwet regularly make clear distinctions between the most recent and one older incarnation of each age-set. While there may be some confusion among informants here, as well as conflation of past events, we would nevertheless argue that when combined with the archaeological data we are inclined to take oral historical accounts of movement, migration and lineage history at face value. We thus favour a 'short' chronology for intensive agricultural settlement in the Kerio Valley and northern Cherangani which spans little more than the last 300 years. Nevertheless we would argue that this 300 year chronology speaks to a deep history of community resilience marked by innovation, specialised production and consistent effective management of regional natural resources through well-developed technologies.

\section{Climate and exchange}


An important feature of this 300-year history of intensive farming is the fact that the Pokot and Marakwet systems have weathered major climatic events. Although high resolution palaeoclimatic and palaeoecological data for the immediate region is not yet available $^{23}$, broader regional records attest to major climatic fluctuations over the course of the last three centuries. It seems fairly clear, for example, that the Pokot system in the Wei wei Valley weathered major repeat dry episodes during the periods c. 1760-1790, 1820$1840,1890-1940$, and $1970-1985^{24}$. However, the region has also seem much more humid conditions including in the early eighteenth century, the mid-late nineteenth century, and much of the second half of the twentieth century ${ }^{25}$. The construction of irrigation channels and new settlement seems to have occurred during both wet and dry periods and although the data is not currently highly resolved enough to analyse whether the pace of construction and change increased or decreased alongside climatic events, it is clear that the overall system seems to have effectively survived such fluctuations.

We might speculate further that agricultural systems such as those of the Marakwet and Pokot, with inherent flexibility (see below) and strong social and technological institutions of ecological management - such as water capture and distribution (irrigation), soil conservation (terracing, mulching, manuring) and patterns of fallowing and croprotation - might actually have acted to buffer more vulnerable regional communities at times of stress. This might have included influxes of pastoralists and/or extensive exchanges with surrounding pastoral communities. Another aspect of this 300-year history which has been poorly explored is therefore the nature and extent of the networks which exist between different farming, pastoral and foraging communities in the Kerio Valley and Northern Cherangani Hills. While our data on this topic is currently limited there have clearly been a wide range of inter-community and cross-ecological relationships based on kinship, marriage, initiation and formal exchange friendships and we have begun to explore these issues elsewhere. ${ }^{26}$

\section{Crops and ecology through time}

If these farming systems have responded well to climate change and actively drawn on broader variations in ecology and resource, another related but poorly understood 
dynamic has been the innovative adoption of new crops and cultivars within pre-existing ways of doing. While considerable further archaeobotanic research is required, the region has a clear history of successive crop introductions. Recent preliminary archaeobotanic studies in Tot-Sibou Marakwet have identified the presence of more than forty food crops/plants including at least nine wild and famine foods. These include twenty-two regularly recurring plants found under-cultivation and in local markets, of which four have African origins, nine Asian and nine American ${ }^{27}$. The African cereal crops include seven varieties of sorghum (Sorghum bicolour) and fifteen varieties of finger millet (Eleusine coracana), of which at least five represent land-races with significant historical and archaeobotanical potential and a range of more recent hybrid varieties. It seems likely, but as yet unproven that the earliest phases of farming in both Pokot and Marakwet relied on a combination of sorghum, finger millet and leafy greens, but it is unclear exactly when varying varieties of peas, beans and certain other African, Asian and New World vegetables arrived. It is quite possible that many of these cultivars pre-date the colonial period, although it is also clear that a wide range of new crops were introduced in the early twentieth century including cassava, cowpeas, bananas, onions and mangoes. These were followed by varieties of maize and various colonial agricultural officers are accredited with introducing new varieties of these and establishing new test plots ${ }^{28}$. Such introductions have continued throughout the twentieth century with new hybrid varieties of maize, finger millet and sorghum alongside other, beans, peas, fruits and vegetables.

While we are yet to write a detailed history of these successive crop introductions, the broader perspective is one of innovative adoption within pre-existing tried and trusted frameworks. In Pokot maize is now widespread but finger millet in particular and sorghum to a lesser extent remain prevalent. Moreover, families continue to preserve stocks of these seed as insurance for particularly dry years and it seems likely that there are complex exchanges of crop varieties across the region which result in the maintenance of species diversity. ${ }^{29}$ In Marakwet the persistence of finger millet and sorghum alongside maize is particularly striking as is the ample evidence of the maintenance of several non-commercial varieties of finger millet and sorghum. Both communities have thus adopted a wide range of novel plant species, but despite various colonial and post-colonial initiatives (see below), they have resisted trends towards mono-culture (especially overt reliance on maize) and 
large-scale cash cropping. In contrast, continuity of irrigation structures and settlement patterns across time attest to the maintenance of a general pattern of cultivation into which novel varieties have been accommodated rather than wholesale changes to the layout, timing or technology of farming. Instead primary focus seems to remain not so much on the specific crops grown but on the ecological balancing of land and fertility with population size and on sustainable kin-based agricultural management structures including patterns of land tenure, fallowing and nutrient regeneration, and the management and maintenance of communal structures such as irrigation channels.

We would argue therefore that Marakwet and Pokot farmers not only understand the routines of cultivation, but they also understand the ecological limits of the system in relation to yields, climate soil fertility and water. They also fully appreciate the social demands on this production system; how much each household requires, how far household aims and ambitions can be satisfied, how far seasonal and life cycle events change demands on production etc. Marakwet and Pokot farmers are thus able to work within the thresholds of variation to accommodate new varieties, new demands and climatic flux without overstretching ecological limitations. This flexibility is especially apparent in data concerning irrigation and land-use.

\section{Settlement, irrigation and land-use in the twentieth century}

"It is important that the sustainability of indigenous irrigation systems is proven and not simply assumed." ${ }^{30}$

Information on the twentieth century history of the agricultural Pokot and Marakwet is detailed and we here offer merely a broad outline of major trends with regard to settlement, irrigation and land-use. Archaeological and ethnographic work both in the Wei wei Valley, Pokot and across the Marakwet region conducted over several years attests to widespread but small scale shifts in settlement and the regular reorganisation and updating of irrigation and land-use over the twentieth century ${ }^{31}$.

As already noted, in the Wei wei Valley the twentieth century has seen the continuation of earlier trends towards gradual movement up and into the valley. This process includes the abandonment of settlements and irrigation features in the north and 
the establishment of new settlements and new irrigation features to the south. This process occurs from one generation to the next, with some children moving away from their parent's homes to find new land and resources. It is further borne out in repetitive patterns of clan land holdings which attest to the regular (c. every 100 years) abandonment of certain clan lands and the establishment of new clan lands on the fringes of the current system ${ }^{32}$. Detailed mapping of both past and present habitation and their archaeological dating (see above) strongly suggests that this process has occurred over the last two centuries without major increases in population density. It thus raises questions about the nature of agricultural intensification under situations of stable population pressure.

In Marakwet, patterns of shifting settlement are less clear and likely involve shifting fields with longer fallowing and movements 'up' and 'down' the escarpment rather than whole-scale movements of people. Nevertheless, have argued elsewhere that 'intensification', through soil conservation measures (terracing, manuring, mulching, afforestation) and irrigation, alongside fluid movement around the landscape are coterminous solutions to issues of access to, and management of, land within a kin-based patrilineal system of land tenure ${ }^{33}$. In Pokot farmers thus 'invest' (intensify) heavily in the land that they have, but over one or more generations, increasing sub-divisions of land between siblings results in localised pressures, out-migration and the cultivation of new lands at the fringes of the system. It may also result in abandonment and degradation but with the latter likely resulting from the cessation of previous conditions of land management rather than direct 'overworking'. These data further suggest that while the Pokot system of cultivation has sustained constant population densities over the last two centuries or more, it has done so through the dynamic ability to gradually move and reorganise across the landscape.

In Marakwet similar processes are evident in more recently acquired data. Extensive GPS mapping of the Marakwet irrigation system has recorded 91 irrigation furrows totalling some $315 \mathrm{~km}^{34}$. While we are currently unable to absolutely date all of these channels we are able to compare the system as recorded in 2011 with that recorded by Robert Soper in 1979-80. ${ }^{35}$ This comparison indicates the development of thirty new main irrigation channels totalling over $60 \mathrm{~km}$ of new irrigation as well as the abandonment of five channels over the last thirty years (Fig.3). This includes the construction of new channels across the 
entire Marakwet area from Arror northwards, however, the vast majority of new channels occur in the northern Embobut region between the settlements of Tot and Chesegon (Fig.4). These new channels attest to considerable expansion and re-organisation of irrigation and land-use over the last three decades. There is some contrast here with Pokot in that it seems likely these new channels support increases in overall population size, but they also likely represent longer-term population movements stemming from localised population pressures within the similar system of patrilineal landholdings.

Farming in Marakwet also differs to Pokot with regard to its more complex dual system of household semi-permanent fields at the foot of the escarpment alongside communally cultivated shifting fields towards the Kerio River ${ }^{36}$. The system of shifting fields likely allows for greater flexibility to increase annual cultivation areas and thus accommodate increases in population density. Population surveys across the region certainly attest to considerable increases in population ${ }^{37}$, and thus suggest that the system is able to manage increased demands on production. While the signature for wholesale population movement over generational timescales is less clear in Marakwet and considerably more work is required to extend this analysis into the early twentieth century and beyond, the irrigation channel data nevertheless attest to a dynamic temporal processes of movement, expansion and re-organisation and the ability to accommodate population change. Our current data certainly does not show decline or degradation of the agricultural system and many indicators suggest quite the opposite ${ }^{38}$.

In both Pokot and Marakwet our data thus attests to fairly vibrant systems of cultivation which have been largely able to accommodate population changes and/or sustain balanced population densities over the twentieth century and beyond without largescale environmental degradation. Looked at from a historical perspective these systems work because they allow for certain degrees of flexible movement around the landscape. At any one time, part of the system may appear to be in decline (the abandonment of settlements, fields and irrigations channels, erosion, soil depletion etc) but other parts will be experiencing new (or renewed) settlement, the construction or shifting of irrigation features and the planting of new fields. Such change at generational scales and across wide landscapes may be partially imperceptible to those engaged within the system, but they are often especially overlooked by outside analysts, policy makers and developers who spend 
only short periods conducting the research on which they base their interventions - this may in part explain why such interventions are often largely ineffective.

\section{Colonial and post-colonial agricultural development interventions}

In contrast to much of the data presented above, many external approaches to farming in Marakwet and Pokot have often painted images of doom and gloom. Early writers on the Marakwet including both Henning and Huxley ${ }^{39}$ describe the system of irrigation but suggest that it is inefficient and in need of modernisation. In the first half of the twentieth century a number of colonial agricultural interventions established test-plots to modernise and introduce new $\operatorname{crops}^{40}$. In the Wei wei valley this included a demonstration plot established by the government African school in Kapenguria. The plot experimented with maize, coco beans, groundnuts, sweet potatoes, cassava, pigeon peas and bananas and was followed by additional plots at varying altitudinal ranges ${ }^{41}$. In Marakwet various early twentieth century demonstration plots saw the introduction of an even wider array of 'cash crops' including tobacco, cotton, sisal, pineapples, chilies, castor, mangoes, pawpaw, sugar cane and varieties of banana ${ }^{42}$.

The Marakwet and Pokot were also not insulated from broader colonial concerns over soil erosion, emanating from the dust bowl experience of the American southwest ${ }^{43}$. By the early 1940s agricultural officers in Pokot had established terrace demonstration plots while cultivation of steeper slopes and deforestation were discouraged ${ }^{44}$. The fact that a wide variety of terracing and other soil conservation measures were likely already practiced, seems to have been largely overlooked ${ }^{45}$. Towards the end of colonial rule, government interest shifted towards irrigation and considerable sums were allocated under the African Land Development Program (Aldev) to develop irrigation in Marakwet. As recounted by Kipkorir $^{46}$, this included an assistant development officer posted to Endo (northern Marakwet) with the aims of establishing systems of ridge and furrow along the contour to prevent erosion, to ensure the more efficient use of indigenous irrigation, and to introduce cash crops. These activities included 'up-grading' of indigenous irrigation structures with concrete and plastic piping; but they also sought to revise the historically grounded management and allocation of water by making it available to all users irrespective of deeper understandings of ownership, labour, kinship and obligation. Attempts to introduce 
tractor ploughing similarly clashed with deeper understandings of land-tenure, communal vs. household labour and thus the traditional size of plots (itself partially also a function of the availability of irrigation water) ${ }^{47}$. Similar Aldev-led irrigation interventions also failed in Pokot and by the early 1960's these attempts had largely been abandoned.

As Kipkorir notes these interventions failed because they attempted to substitute a new system for the existing one rather than strengthening the effective traditional system. They particularly subverted the responsive capacities of the Kokwa to pragmatically and flexibly manage the wider agricultural landscape. Writing from his position in the early 1980s, Kipkorir is not only in a position to lament these failures but also to note concern over the next wave of proposed developments scheduled for the 1980s. District development plans had already been widely commissioned in the late 1970s and early 1980s and targeted a range of commercial activities. These development initiatives particularly focussed on the Kerio Valley Development Agency (KVDA) established in 1979 and included plans for a Fluorspar mine, tourist resort and new road and rail links, none of which have ever fully came to fruition ${ }^{48}$. Agricultural initiatives included irrigation schemes in Marakwet and Pokot and the expansion of cotton production. Among these early KVDA activities was a feasibility study for an irrigation scheme at the confluence of the Embobut and Kerio Rivers to provide agricultural water to both the Marakwet and Pokot. This latter plan also did not materialise, but it is worth noting in light of more recent irrigation developments discussed below. As Kipkorir critically notes these plans continued to view local agriculture as 'retrogressive and obscurantist' ${ }^{49}$ without actually producing evidence for these views.

Throughout the 1980s and 1990s the KVDA and a number of other organisations (notably World Vision, the Catholic Church) continued to engage in agricultural development activities. A full history of these interventions is not possible in this short space, but they included the regular donation of funds and construction of concrete irrigation repairs across Marakwet and Pokot $^{50}$. They also involved the larger-scale renovation of irrigation channels in Arror (southern Marakwet) and at Tot (northern Marakwet) and the establishment of small KVDA-led cash cropping schemes, including cotton, rice, grain-seed and sugar-cane at $\operatorname{Tot}^{51}$. Small-scale repairs of irrigation furrows seem to have been fairly effective since they largely supported and reinforced the existing 
system of agricultural practice. The larger-scale renovation of irrigation channels seems to have a more mixed impact. In Tot the KVDA constructed a furrow that was taken-off at the foot of the escarpment from the south-side of the Embobut River and seems to have been largely used to supply the KVDA's own test plots on land donated to the KVDA by the community $^{52}$. However, poorly located, the channel went out of use along with the KVDA plots. In Arror larger channels remain in use by the community today although our survey team noted considerable problems with erosion along these in $2011^{53}$.

In Pokot the KVDA established a major irrigation project at Wei wei in 1987 and with funding from the Italian government since $1990^{54}$. Although we are currently not aware of any formal external assessment, the scheme appears to have been fairly successful and new funds have been allocated for its expansion ${ }^{55}$. However, the scheme appears to operate partially outside of the local economy and as part of closed cooperative agreement with the Kenya seed corporation - indeed the scheme is at least partly designed to produce seed rather than grain for consumption ${ }^{56}$. The 1800 people on the scheme come from a wide range of backgrounds (including Pokot pastoralists) but most families in the region continue to make use of older irrigation and cultivation techniques and continue to do so without interaction with the scheme ${ }^{57}$. The scheme also does not appear to contribute substantially to local food pathways by placing produce into the local market although it likely contributes in other less direct ways. A fuller assessment of the Wei wei scheme would seem to be a future research priority.

The most recent agricultural development in the Kerio Valley has been the establishment of a new 500-acre irrigation scheme funded by the Canadian Red Cross. Begun in 2012 and operational for the first time in 2014, the scheme takes water in a major pipeline across the floor of the Kerio Valley and even across the river itself, irrigating 250 acres on the Marakwet side and 250 on the Pokot side of the valley. The scheme makes use of a fixed network of irrigation pipes and sprinklers and commercial seed, inorganic fertilisers and pesticides have been supplied for the first season. The scheme aims to reduce regional food security and develop cash cropping and we have been able to extensively record its development. While a number minor issues have already been noted by local farmers, the success of the scheme will clearly be determined over the coming years. Of particular note at the current time is the fact that the scheme is designed to operate in a 
wholly different manner to present-day cultivation in the region. The system of fixed piped irrigation stands in stark contrast to the fluid and flexible system of shifting irrigation and cultivation traditionally employed in this part of the Kerio Valley. How soil fertility will be maintained and maximised over the coming years is thus a major subject for future investigation. Certainly the scheme seems to be based on the idea that local and precolonial practices are inefficient and that modern solutions are required. It also appears to assume that this is most effective way to solve perceived issues of food insecurity although the long-term record of food shortage it yet to be written.

\section{Environmental Narratives}

As has already been noted, the bulk of twentieth century agricultural interventions appear to have been predicated on the notion that 'traditional' farming was inefficient and in some cases ecologically unsound. Yet as Kipkorir noted for Marakwet in 1983 little evidence has ever been put forward to support such assumptions. In fact a number of academic studies have offered quite striking contrasts, noting challenges but largely reporting on the broader ecological soundness and productivity of these agricultural systems. These include multiple contributions to the volume Kerio Valley, past, present and future edited by Kipkorir et al. ${ }^{58}$ as well as locational profiles by Hogg ${ }^{59}$ and Dietz et al. ${ }^{60}$. Soper $^{61}$ in particular notes how Marakwet irrigation is likely to have a long and fairly sustained history while contributors to the Kipkorir et al. volume were generally in agreement that development should reinforce rather than alter existing ecological practices. We would argue that our data, presented above and elsewhere, contributes a similar perspective and extends analysis of these enduring systems across time.

There has been and remains therefore a miss-match between the views of many academics and those of external developers. In fact, if anything, the brief historic outline above suggests that it is the 'external' agricultural development initiatives that have proven rather fleeting ${ }^{62}$. New initiatives seem to emerge and fade every decade or so but they do so against the back drop of enduring, innovative and adaptable local practice. Whether the two most recent major developments, the irrigation schemes at Wei wei and Tot, will also fade or make more lasting contributions to the region remains to be seen. 
However, while some academic trends have emphasised the contrast between local persistence and external narratives of intervention and modernisation, other academic research trends have not been unaffected by broader global environmental concerns. Indeed a brief account of more recent academic environmental concerns voiced in Marakwet also serves to highlight how external assumptions and priorities can drive certain kinds of environmental agenda and limit the conclusions drawn when there is an absence of connected and temporally and spatially broader empirical data. For example, while soil erosion and maintenance was a major concern in the colonial period, Adams and Watson's work $^{63}$ exemplifies renewed concerns over soil erosion in the 1990s. The study aims to question assumptions about the sustainability of irrigation farming in Marakwet and points to erosion as one possible challenge to sustainability. While they are cautious and claim that the future impact of erosion on Marakwet farming is unclear, they do re-raise the spectre of disaster and degradation echoed in the earlier developmental agenda ${ }^{64}$. In contrast, Adams and Watson do point to the way in which farmers themselves both acknowledge and manage erosion as part and parcel of their daily lives. Our data firmly confirms the view that Marakwet and Pokot farmers have effectively managed environmental resources through time, but more importantly we would argue that longer-term temporal patterns of fluid movement across the landscape suppose the longer-term inter-generational management of soil erosion through patterns of abandonment, movement and new settlement. Although further data is required, it seems quite likely that soil erosion, as a major yet un-materialised concern of the last century, is not so much an immanent crisis, but a managed dynamic of Marakwet farming.

The spectre of crisis has been raised even more recently by Kipkorir and Kareithi ${ }^{65}$ who argue that there has been a general decay of irrigation structures in the Tot-Sibou region of Marakwet which has led to food insecurity. Their work largely focuses on questionnaire based surveys of local farmers and we do not doubt that farmers see regular breaks and damages to irrigation furrows as a major problem. However, our data demsontrate that challenges, breakages and repairs do not indicate overall 'decay'66. Instead repairs and renovations are common and the total number and length of irrigation channels has clearly increased considerably over the last thirty years (see above and Figures 3 and 4). This increase in irrigation structures and the incredible investment placed in them 
seems quite contradictory to Kipkorir and Kareithi's statement of general decline. Our concern here is not with Kipkorir and Kareithi's data per se, since there are many challenges that local farmers must overcome ${ }^{67}$; but rather that such challenges have likely always been an element of Marakwet farming and that the is key to understand how such challenges and their responses have changed through time. While patterns of 'maintenance' have changed, the system as a whole still appears to work and indeed to have expended over the last 30 years.

Kipkorir and Kareithi do also mention changes caused by climate and population ${ }^{68}$, but they do not focus on these and instead see the supposed 'decay' of Marakwet irrigation as due to a general lack of maintenance coupled with 'environmental degradation' derived from 'over exploitation' ${ }^{69}$. Caretta and Börjeson ${ }^{70}$ focus primarily on gender balances of labour and decision-making but relate this to climatic 'adaptive capacity' rather than to issues of soil erosion, irrigation management or environmental degradation. Their concern is with empowering gendered solutions to the assumed impending climatic crisis. We feel however that this compartmentalising of different factors such as erosion, maintenance, climate and population does a disservice to the complex interconnections of these and other factors which are well understood and often well balanced - although not without challenge - by Marakwet farmers themselves.

\section{Conclusion: Cultural resilience and agricultural development}

While the Marakwet and the Pokot have always been beset by agricultural and ecological challenges, their technologies of life contain inherent flexibilities with regard to movement, innovation and improvisation which we view as a form of 'cultural resilience'. Over the last 200 years or more, these flexibilities have allowed for the accommodation of population changes, the weathering of climatic fluctuations, the management of erosion and the incorporation of new crops and forms of exchange. But at the same time they have largely retained broader balances between land, water, fertility and population. External 'development' interventions have largely come and gone against this background and unlike the tales of doom and gloom promoted by those self-same commentators, our impression of the Marakwet and Pokot farming is one of enduring stability over the long durée. This is 
not to say that today's challenges (deforestation, water shortage, climate change etc) are not quantitatively different from those of the past, nor should this conclusion breed complacency. But we would argue that the forthcoming challenges require much greater examination and that contemporary interventions would be best served by understanding these longer-scale and spatially broader dynamics such that modern interventions reinforce rather than contradict the long-standing culturally resilient approach of the community itself.

Ultimately, one can expend considerable energy and finances in designing interventions and conducting feasibility studies, but unless such studies contain a considerable historical understanding they will always be based on fairly short-term and localised data which may not fully represent the system over broader temporal and spatial scales. To overlook the longer term context of an ecological system while attempting to reengineer that system is thus not just an oversight, but it is fundamentally bad science. It is also economically inefficient to reinvent the failures of past development schemes and it is ethically unsound to intervene in a community's way of life (however well meaning) without exploring and, where possible, first reinforcing the community's own technologies of environmental management.

Our future research will focus on exploring and quantifying the challenges of climate and ecological management that will likely be faced by the Pokot and Marakwet in the coming decades. Alongside this we aim to explore how these challenges can be reconciled with the ambitions and aspirations for the future as expressed by members of the community themselves. At the present time there is no reason to assume that the coming challenges will precipitate a dissolution of these communities - indeed this paper has shown how major challenges and changes in the past have not had such an effect despite nearly a century of warnings by various outsiders that the 'end was nigh'. We believe that the best way forward in terms of building sustainable and prosperous futures is first to ensure that all claims in the present are tempered by a historical hindsight that cautions against futurist assumptions. From this position we believe it is much easier to avoid repeating the past and instead to move forward with both the challenges and aspirations for the future in mind. 


\section{Bibliography}

Adams, William M. "Irrigation, erosion and famine: visions of environmental change in Marakwet, Kenya." In The lie of the land: Challenging received wisdom on the African environment, edited by Melissa Leach and Robert Mearns, 155-67. Oxford: James Currey, 1996.

Adams, William M. and David M. Anderson. "Irrigation before development: indigenous and induced change in agricultural water management in East Africa." African Affairs 87 (1988): 519-535.

Adams, William M. and Elizabeth E. Watson. "Soil erosion, indigenous irrigation and environmental sustainability, Marakwet, Kenya." Land Degradation and Development 14 (2003): 109-122.

Adams, William M., Elizabeth E. Watson and S.K. Mutiso. "Water, rules and gender: water rights in an indigenous irrigation system, Marakwet Kenya." Development and Change 28 (1997): 708-730.

Anderson, David M. "Depression, dust bowl, demography, and drought: The colonial state and soil conservation in East Africa during the 1930s." African Affairs, 83 (1984): 321-343.

Anon. Business Daily Africa, 25/06/13 "Irrigation scheme in West Pokot gets Sh80 million boost", Business Daily Africa, 25 June 2013. Retrieved from http://www.businessdailyafrica.com/Corporate-News/Irrigation-scheme-in-West-Pokotgets-Sh80-million-boost/-/539550/1894378/-/wkh73fz/-/index.html. Accessed 27 November 2014.

Bollig, M. "An outline of pre-Colonial Pokot history." Afrikanistiche Arbeitspapiere 23 (1990): 73-91.

Caretta, M.A. and L. Börjeson. "Local gender contract and adaptive capacity in smallholder irrigation farming: a case study from the Kenyan drylands." Gender, Place \& Culture: A Journal of Feminist Geography. Published online, 21 Feb 2014. DOI: 10.1080/0966369X.2014.885888

Critchley, Will. "Agricultural development in Marakwet: some controversial issues." In Kerio Valley: Past, Present and Future, edited by B.E. Kipkorir, Robert C. Soper and J.W. Ssennyonga, 1926. Institute of African Studies, University of Nairobi, 1983.

Davies, Matthew I.J. "Economic specialisation, resource variability and the origins of intensive agriculture in Eastern Africa". Rural Landscapes, in press.

Davies, Matthew I.J. "The temporality of landesque capital: farming and the routines of Pokot life." In Landesque capital: the historical ecology of enduring landscape modifications, edited by Thomas Håkansson and Mats Widgren, 172-196. Place: Left Coast Press, 2014.

Davies, Matthew I.J. "Forced moves or just good moves? Environmental decision making among Pokot farmers, northwest Kenya." pp. 57-76. In Humans and the environment: new archaeological approaches for the $21^{\text {st }}$ century, edited by Matthew I.J. Davies and F.M. M'Mbogori, 57-76. Oxford: Oxford University Press, 2013.

Davies, Matthew I.J. "Some thoughts on a 'useable' African archaeology: settlement, population and intensive farming among the Pokot of northwest Kenya." African Archaeological Review 29 (2012): 319-353. 
Davies, Matthew I.J. "Wittfogel's dilemma: heterarchy and ethnographic approaches to irrigation management in Eastern Africa and Mesopotamia." World Archaeology 41 (2009): 16-35.

Davies, Matthew I.J. "An applied archaeological and anthropological study of intensive agriculture in the Northern Cherangany Hills, Kenya." D.Phil thesis, University of Oxford, 2009.

Davies, Matthew I.J. "The irrigation system of the Pokot, northwest Kenya." Azania 43 (2008): 50-76.

Davies, Matthew I.J., T.K. Kipruto and Henrietta L. Moore. "Revisiting the irrigated agricultural landscape of the Marakwet, Kenya: tracing local technology and knowledge over the recent past". Azania: Archaeological Research in Africa: in press.

Davies, M.I.J., Dupeyron, A. and Moore, H.L. 2014. "Mobile internet technologies and the possibilities for public archaeology in Africa: Marakwet, Kenya." Antiquity Project Gallery http://journal.antiquity.ac.uk/projgall/453.

Dietz, Ton. Pastoralists in Dire Straits: Survival Strategies and External Interventions in a Semi-arid Region at the Kenya/Uganda Border: Western Pokot, 1900-1986. Koninklijk Nederlands Aardrijkskundig Genootschap: Instituut voor Sociale Geografie, Universiteit van Amsterdam, 1987.

Dietz, Ton, A. van Haastrecht and Henrietta L. Moore. "Locational Development Profile: Endo, Mokoro and Embobut locations, Elgeyo Marakwet District, Kenya." Iten: Arid and Semi-Arid Lands Programme, 1987.

French, ?. et al. "Geo-archaeological assessment of the area around Tot-Marakwet, Kenya," published online at https://farminginafrica.wordpress.com/2014/01/13/geoarchaeologicalassessment-of-the-area-around-tot-marakwet-kenya/ Accessed ?? ??? ????.

Hennings, R.O. "The furrow makers of Kenya." Geographical Magazine 12 (1941): 169-179.

Hogg, Richard. "Pokot traditional irrigation and its future development". Unpublished consultancy report, Kapenguria A.S.A.L., 1984.

Huxley, Elspeth. “African water engineers." Geographical Magazine 32 (1959): 170-175.

Ingold, Tim. "The temporality of the landscape." World Archaeology 25 (1993): 152-174.

Kipkorir, B.E. (with F.B. Welbourn). The Marakwet of Kenya: a preliminary study. Nairobi: East African Literature Bureau, 1973.

Kipkorir, B.E. 1983. "Introduction." In Kerio Valley: Past, Present and Future, edited by B.E. Kipkorir, Robert C. Soper and J.W. Ssennyonga, ix-xii. Institute of African Studies: University of Nairobi, 1983.

Kipkorir, B.E. "Historical perspectives of development in the Kerio Valley." In Kerio Valley: Past, Present and Future, edited by Kipkorir, B.E., Robert C. Soper and J.W. Ssennyonga, 1-11. Institute of African Studies: University of Nairobi, 1983.

Kipkorir, B.E., Robert C. Soper and J.W. Ssennyonga (eds). Kerio Valley: Past, Present and Future. Institute of African Studies, University of Nairobi, 1983. 
Kipkorir, D. and J. Kareithi. "Indigenous Irrigation and Food Security in Tot Division, Kerio Valley, Kenya." Journal of Anthropology and Archaeology 1 (2014): 12-27.

Kipkorir, D and J. Kareithi. "Human and Natural Factors in the Deterioration of Indigenous Irrigation Furrows in Marakwet, Kenya." International Journal of Humanities and Social Science 2 (2012): 113-128.

Kenya National Bureau of Statistics [KNBS]. Kenya Population and Housing Census. Vol. IB. Nairobi: Government Press, 2009.

Moore, Henrietta L.M. Space, Text and Gender: An anthropological study of the Marakwet of Kenya. Cambridge: Cambridge University Press, 1986.

Moore, Henrietta L.M. Still Life: hopes, desires and satisfactions. London: Polity Press, 2011.

Moore, Henrietta L.M. and Matthew I.J. Davies. The Marakwet Community Heritage Mapping Project: Report on the first to third seasons of fieldwork. Unpublished fieldwork reports, McDonald Institute, University of Cambridge, 2011-13.

Nangulu, A. K. "Food security and coping mechanisms in Kenya's marginal areas: The case of West Pokot." PhD. thesis, West Virginia University, 2001.

Östberg, W. "Irrigated fields are wives: indigenous irrigation in Marakwet, Kenya." pp. 197-214. In Landesque capital: the historical ecology of enduring landscape modifications, edited by Thomas Håkansson and Mats Widgren. Place: Left Coast Press, 2014.

Östberg, W. "The Expansion of Marakwet Hill-Furrow Irrigation in the Kerio Valley of Kenya." In Islands of Intensive Agriculture in Eastern Africa, edited by Mats Widgren and John E.G. Sutton, 19-48. Oxford: James Currey, 2004.

Pollard, G., Matthew I.J. Davies and Henrietta L. Moore. "Women, marketplaces, and exchange partners amongst the Marakwet of northwest Kenya." In press.

Rambaldi, G. "Wei Wei Integrated Development Project, Sigor (Kerio Valley) - Kenya, Training, Research and Consolidation Programme." Unpublished report, Lodagri SpA, 1995.

Rambaldi, G. "Small scale irrigation in remote areas: An approach to marketing as contribution to successful project implementation." Unpublished paper presented at the Workshop on 'Experiences and perspectives of Horticultural Smallholder Irrigation Schemes in Kenya Nairobi, Kenya, November 26, 1992', retrieved from http://www.iapad.org/wei_wei_project/docs/paper_92.pdf Accessed on 27 November 2014.

Soper, Robert C. "A Survey of the Irrigation System of the Marakwet." In Kerio valley: Past, present and future, edited by Benjamin E. Kipkorir, Robert C. Soper and J.W. Ssennyonga, 75-95. Institute of African Studies, University of Nairobi, 1983.

Watson, Elizabeth E., William M. Adams and S.K. Mutiso. "Indigenous irrigation, agriculture and development, Marakwet, Kenya." The Geographical Journal 167 (1988): 3124-3141. 


\section{Endnotes}

${ }^{1}$ Kipkorir, "Introduction," x.

${ }^{2}$ Kipkorir, The Marakwet of Kenya; Kipkorir, Soper and Ssennyonga, Kerio Valley; Moore, Space, Text and Gender; Dietz et al. "Locational Development Profile"; Östberg, "The expansion"; Watson, Adams and Mutiso, "Indigenous irrigation".

3 Davies, "The temporality"; Davies, "Some thoughts"; Davies, "A view from the East"; Davies, "An applied archaeological and anthropological"; Davies, "The irrigation system". Most other studies have focussed on the pastoral Pokot.

"Davies, "Some thoughts"; Davies, "The irrigation system"; Davies, Kipruto and Moore, "Revisiting the irrigated".

${ }^{5}$ Ingold, "The temporality".

${ }^{6}$ Davies, "The temporality".

${ }^{7}$ Moore, Space, Text and Gender.

${ }^{8}$ Davies, "Forced moves".

${ }^{9}$ Davies, "The irrigation system"; Davies, Kipruto and Moore, "Revisiting the irrigated".

${ }^{10}$ Davies, "The temporality".

${ }^{11}$ In Marakwet, for example, there are thirteen primary ways of gaining access to land. Moore and Davies "The Marakwet Community Heritage Mapping Project".

12 Davies, "Wittfogel's dilemma"; Adams, Watson and Mutiso, "Water rules and gender".

${ }^{13}$ Davies, Kipruto and Moore, "Revisiting the irrigated"; Dietz et al. "Locational

Development Profile".

${ }^{14}$ Pollard, Davies and Moore, "Women, marketplaces, and exchange". ${ }^{15}$ Ibid.

${ }^{16}$ Although space precludes further discussion, these operate at both communal and household scales in differing contexts.

${ }^{17}$ Bollig, "An outline"; Davies, "An applied archaeological and anthropological", 259; Dietz, Pastoralists in dire straits, 148 . This has also been accompanied over the last 200 years by an increasing Pokot pastoral expansion, westwards into Karamoja (Uganda) and eastwards into Baringo.

${ }^{18}$ Prior to this date the region seems to have been settled by small-stock keeping stone tool and rock-shelter using peoples with a rather different impact on the landscape, see Davies, "An applied archaeological and anthropological", 254-270.

${ }^{19}$ Davies, "An applied archaeological and anthropological", 226-233; Davies, "Thoughts", 337-339.

${ }^{20}$ As already noted these include radiocarbon dates on a number of habitation sites in the Wei wei Valley as well as optical luminescence and thermoluminescence dates from abandoned irrigation features. See Davies, Thoughts", 337 and Davies, "The irrigation system", 70-71.

${ }^{21}$ Supporting oral historical data includes historic sequences of irrigation channel construction based on age-sets and Pokot genealogies. See Davies "The irrigation system" and Davies, "An applied archaeological and anthropological", 158-185 and appendix F.

${ }^{22}$ Moore and Davies, Marakwet Community Heritage Mapping Project.

${ }^{23}$ But see French et al, "Geo-archaeological assessment."

${ }^{24}$ Davies, "Applied archaeological and anthropological", 277-289; Dietz, Pastoralists in Dire Straights, 88-90; Nangulu, "Food security", 10. 
${ }^{25}$ Davies, "Thoughts", 346; Davies, "Applied archaeological and anthropological”, 277-289.

${ }^{26}$ Pollard, Davies and Moore, "Women, marketplaces, and exchange"; Davies, "Economic specialisation".

${ }^{27}$ Jones personal communication. see also Davies "Applied archaeological and anthropological", 52-65 for Pokot

${ }^{28}$ Kipkorir, "Historical perspectives".

29 Jones, personal communication. This crop diversity needs to be explored in much greater detail, not least because it potentially represents an important store of genetic and ecological variation.

${ }^{30}$ Adams and Watson, "Soil erosion,"110.

${ }^{31}$ Davies "Temporality"; Davies "Thoughts"; Davies "The irrigation system"; Davies, Kipruto and Moore, "Revisiting the irrigated".

32 See especially Davies, "Forced moves".

33 Ibid.

${ }^{34}$ Davies, Kipruto and Moore, "Revisiting the irrigated". In this region irrigation canals or channels are commonly referred to in English as 'furrows'.

${ }^{35}$ Soper, "Survey," 75-95.

${ }^{36}$ Davies, Kipruto and Moore, "Revisiting the irrigated".

${ }^{37}$ As much as two-fold between the 1930s and 1984, but with some variation. Dietz et al.

"Locational Development Profile", 37-40.

${ }^{38}$ For example, Kipkorir and Kareithi, "Indigenous irrigation."

39 Henning, "The furrow makers"; Huxley, "African water engineers".

${ }^{40}$ Kipkorir, "Historical perspectives", 6.

${ }^{41}$ Nangulu, "Food security", 99-101.

42 Kipkorir, "Historical perspectives", 6.

${ }^{43}$ Anderson "Depression".

${ }^{44}$ Nangulu, "Food security", 108-109

${ }^{45}$ Davies, "An applied archaeological and anthropological", 77-83.

${ }^{46}$ Kipkorir, "Historical perspectives," 6-7.

${ }^{47}$ Ibid.

${ }^{48}$ See Kipkorir, "Introduction", ix. Dietz et al. "Locational Development Profile". The lack of an all-weather road along the Kerio Valley remains one of the greatest impediments to regional development.

${ }^{49}$ Kipkorir "Introduction", $\mathrm{x}$.

${ }^{50}$ Davies, Kipruto and Moore "Revisiting the irrigated".

${ }^{51} \mathrm{Ibid}$. Other schemes, especially at Arror and elsewhere are beyond the scope of our knowledge.

52 In these 'development' schemes the community often has to give up land which would be otherwise used. They are also often expected to supply labour without clear indication of return.

${ }^{53}$ Davies, Kipruto and Moore "Revisiting the irrigated".

${ }^{54}$ Rambaldi, "Wei Wei"; Rambaldi, "Small scale irrigation".

${ }^{55}$ Anon., "Irrigation scheme in West Pokot".

${ }^{56}$ Rambaldi, "Small scale irrigation".

${ }^{57}$ Rambaldi, "Wei Wei", 7. Davies, "An applied archaeological and anthropological".

${ }^{58}$ Kipkorir, Soper and Ssennyonga, The Kerio Valley. 
${ }^{59}$ Hogg, Pokot traditional irrigation.

${ }^{60}$ Dietz et al. "Locational Development Profile".

${ }^{61}$ Soper, "A survey".

${ }^{62}$ Watson, Adams and Mutiso, "Indigenous irrigation", 82

${ }^{63}$ Adams and Watson, "Soil erosion".

${ }^{64}$ Watson, Adams and Mutiso, "Indigenous irrigation", 113-114

${ }^{65}$ Kipkorir and Kareithi, "Indigenous irrigation"; Kipkorir and Kareithi, "Human and natural factors".

${ }^{66}$ We have GPS-recorded and photographed some 1200 points of interest across the Marakwet irrigation system, the majority of which relate to breakages and repairs at a variety of scales and different periods in time. See Davies, Kipruto and Moore, "Revisiting the irrigated".

${ }^{67}$ For example, Kipkorir and Kareithi "Indigenous irrigation," state that they start "with the working hypothesis that decay of Marakwet furrows has reduced food crop production in the division and contributed to food insecurity", 15.

${ }^{68}$ Ibid., 16.

${ }^{69}$ Kipkorir and Kareithi, "Human and natural factors", 114.

70 Caretta and Börjeson, "Local gender contract". 